\title{
Gas exchanges and carbohydrate metabolism in orange trees with citrus variegated chlorosis
}

\author{
Mara de Menezes de Assis Gomes ${ }^{1 *}$, Ana Maria Magalhães Andrade Lagôa ${ }^{2}$, \\ Eduardo Caruso Machado ${ }^{2}$, Camilo Lázaro Medina ${ }^{3}$ and Marcos Antônio Machado 3
}

\begin{abstract}
${ }^{1}$ Setor de Fisiologia Vegetal/CCTA/LMGV, Universidade Estadual do Norte Fluminense, Av. Alberto Lamego, 2000, CEP 28015-620, Campos dos Goytacazes, RJ, Brasil; ${ }^{2}$ Centro de Ecofisiologia e Biofísica, Instituto Agronômico de Campinas, CP 28, CEP 13001970, Campinas, SP, Brasil; ${ }^{3}$ Centro de Citricultura Sylvio Moreira/IAC, Cordeirópolis, SP, Brasil; *Corresponding author: alagoa@iac.sp.gov.br
\end{abstract}

Received: 21/10/2002, Accepted 10/03/2003

Gas exchanges, sucrose, starch and reducing sugar contents were analyzed in leaves of orange trees with and without Citrus Variegated Chlorosis (CVC), a disease caused by the bacteria Xylella fastidiosa. Healthy plants (HP) and diseased plants (DP) were evaluated 20 and 26 months after bacterial inoculation, in October 1998 and April 1999, respectively. On the first evaluation date, $\mathrm{CO}_{2}$ assimilation rates for $\mathrm{HP}$ were greater than DP in the early morning and midday, but on the second date they were greater in HP all along the day. On the first date, there was an increase in the sucrose content of DP at 15:00 $\mathrm{h}$ and 17:00 $\mathrm{h}$ in relation to HP. On the second evaluation date, DP presented greater reducing sugar content only in the early morning while sucrose content showed a decrease at 15:00 h. Also, on the second date, the concentrations of starch were always lower for DP compared to HP. It is suggested that this variation in starch levels might be related to energy availability in DP, as they also showed lower photosynthetic rates. Soluble sugars did not show any correlation with the disease and photosynthetic parameters.

Key words: Citrus sinensis L., photosynthesis, reducing sugars, starch, sucrose, Xylella fastidiosa.

Trocas gasosas e metabolismo de carboidratos em laranjeiras com clorose variegada dos citros: As trocas gasosas e as concentrações de sacarose, amido e açúcares redutores foram analisadas em folhas de laranjeiras com e sem Clorose Variegada dos Citros (CVC), doença causada pela bactéria Xylella fastidiosa. Plantas sadias (PS) e plantas doentes (PD) foram avaliadas 20 e 26 meses após a inoculação da bactéria, em outubro de 1998 e abril de 1999, respectivamente. Na primeira data de avaliação, as taxas de assimilação de $\mathrm{CO}_{2}$ em PS foram maiores do que em PD nas primeiras horas da manhã e ao meio-dia, mas na segunda data de avaliação elas foram maiores em PS durante o dia todo. Na primeira data, houve aumento no conteúdo de sacarose de PD às 15 h e 17 h em relação ao de PS. Na segunda data, PD mostrou maior conteúdo de açúcares redutores somente no período da manhã, enquanto o conteúdo de sacarose apresentou decréscimo às $15 \mathrm{~h}$. Na segunda data, as concentrações de amido foram sempre menores em PD, quando comparadas com as de PS. As variações de amido podem estar relacionadas com a disponibilidade de energia para atividades metabólicas de PD, uma vez que elas também apresentaram taxas de fotossíntese mais baixas. Os teores de açúcares solúveis não mostraram qualquer relação com a doença ou parâmetros de fotossíntese.

Palavras-chave: açúcares redutores, amido, Citrus sinensis L., fotossíntese, sacarose, Xylella fastididosa.

\section{INTRODUCTION}

Citrus Variegated Chlorosis (CVC) is a disease caused by Xylella fastidiosa, a fastidious xylem-limited bacteria, that is transmitted by sucking insects, mainly sharpshooters of the Cicadellidae family (Hill and Purcell, 1995, 1997). CVC was first identified in Brazil in 1987 in orchards located in the Triângulo Mineiro, Minas Gerais State, and the North and Northeast of the State of São Paulo. 
Nowadays, CVC is found infecting nearly all the citrus growing areas of Brazil, affecting mainly sweet orange trees (Chang et al., 1993; Lima et al., 1996).

The leaves of plants with CVC present generalized chlorosis mainly in the upper part of the canopy and they are generally smaller than healthy leaves, with lower $\mathrm{Zn}$ and $\mathrm{K}$ contents and small blisters on the abaxial surface (Rossetti, 2001). These blisters burst forming small lesions that correspond to the chlorotic spots on the adaxial surface. The fruits of these plants are small, hard and yellow, making them undesirable for the market and juice industry (Rossetti et al., 1991). Most of the symptoms of this disease, such as marginal leaf necrosis, slow growth in the spring and declining vigor leading to plant death, suggest an interference in the water conducting system (Hopkins, 1989).

Orange trees with CVC present symptoms of water stress which are associated with significant decreases in $\mathrm{CO}_{2}$ assimilation and transpiration rates (Machado et al., 1994). Compared with other perennial species, $\mathrm{CO}_{2}$ assimilation rates in citrus leaves are low (between 8.0 and $\left.10.0 \mu \mathrm{mol} . \mathrm{m}^{-2} \cdot \mathrm{s}^{-1}\right)$. However, the evergreen leaves of citrus can assimilate carbon throughout the year and thus compensate this low supply (Waring, 1991; Brakke and Allen, 1995; Goldschmidt and Koch, 1996). Citrus leaves are an important carbohydrate reserve organs and starch is the principal storage carbohydrate (Goldschmidt and Golomb, 1982).

The aim of this work was to study the gas exchanges and the carbohydrate metabolism in orange trees with CVC.

\section{MATERIAL AND METHODS}

Plant material and bacterial inoculation: The sudy was carried out at the Centro de Citricultura Sylvio Moreira, Instituto Agronômico de Campinas, Cordeirópolis (22 ${ }^{\circ} 34^{\prime} \mathrm{S} ; 4^{\circ} 34^{\prime} 0 ; 689 \mathrm{~m}$ altitude), SP. One-year-old "Pera" orange trees (Citrus sinensis L. Osbeck) grafted on "Rangpur" lemon (Citrus limonia Osbeck) rootstocks were transplanted to $100 \mathrm{~L}$ pots containing a mixture of earth, sand and organic matter $(3: 1: 1)$ with an individual drip irrigation system. The plants were kept in a greenhouse, completely closed to prevent the passage of insects.

$X$. fastidiosa bacterium was inoculated following the method developed by Medina et al. (1998). After six months of inoculation all the inoculated plants presented a positive result after PCR analysis (Pooler and Hartung, 1995). Five healthy plants (HP) and five diseased plants
(DP) were evaluated after 20 (October 1998) and 26 months (April 1999) of bacterial inoculation.

$\mathrm{CO}_{2}$ assimilation, stomatal conductance and transpiration rates: $\mathrm{CO}_{2}$ assimilation rates (A), stomatal conductance $\left(\mathrm{g}_{\mathrm{s}}\right)$ and transpiration (E) were measured on one-year-old leaves of previously selected branches. In the case of DP, leaves with "type $3 \%$ " disease symptoms (Amorim et al., 1993) were chosen for the analyses. $\mathrm{CO}_{2}$ assimilation, stomatal conductance and transpiration were measured at 8:30, 9:30, 12:00 and 15:30 h using a portable Infra Red Gas Analyzer (Licor, model Li 6200).

Carbohydrate analysis: The same leaves used in the IRGA measurements were used for carbohydrate analysis. Leaves were harvested at 9:00, 12:00, 15:00 and 17:00 h. The leaves were cut from the branches, plunged in liquid nitrogen and maintained at $-70{ }^{\circ} \mathrm{C}$ for $72 \mathrm{~h}$ before being ground and freeze-dried. Leaf tissue $(150 \mathrm{mg})$ was extracted twice with hot $80 \%$ ethanol $\left(70{ }^{\circ} \mathrm{C}, 20 \mathrm{~min}\right)$ and the supernatants pooled for analysis. The resulting residue was extracted twice with perchloric acid $\left(70{ }^{\circ} \mathrm{C}, 30 \mathrm{~min}\right)$ and the pooled supernatants filtered and the volume made up to $100 \mathrm{~mL}$ with distilled water. The soluble sugars in the supernatants from the alcoholic and acid extractions were measured as described by Somogyi (1952).

Climatic data: Dry and wet-bulb temperatures used for vapor pressure deficit (VPD) calculations were obtained by a mini meteorological station installed inside the greenhouse. Photosynthetic photon flux density (PPFD) was obtained with a sensor located in the Li-6200 chamber.

\section{RESULTS AND DISCUSSION}

The depression in photosynthesis at midday, observed in both treatments at the two evaluation dates (figures $1 \mathrm{~A}$ and 1B), is a typical phenomenon of the citrus fruit tree. It occurs as a result of the high evapotranspiration resulting from the rise in VPD (Sinclair and Allen, 1982; Vu and Yelenosky, 1988a; Syvertsen and Lloyd, 1994; Medina et al., 1999). The midday depression in photosynthesis also occurs in other species such as Arbutus unedo, whose stomata can close in dry atmospheres because they have developed great sensitivity to changes in humidity (Raschke and Reseman, 1986). These authors considered that midday depression occurred simultaneously with the 
stomatal responses but, in some cases, the decline in photosynthesis preceded the decrease in stomatal conductance. It is well known that the gas exchange processes occurring in the leaves are correlated because both the $\mathrm{CO}_{2}$ and water vapor fluxes are conditioned by PPFD, VPD and stomatal opening (Germaná and Sardo, 1996). Stomatal conductance in citrus increases as the PPFD comes close to saturation, at around $500 \mu \mathrm{mol}$ $\mathrm{m}^{-2} \cdot \mathrm{s}^{-1}$ which represents $25 \%$ of full sun irradiation (Syvertsen, 1999).

On the first evaluation date, photosynthetic rates began to decline at 9:00 $\mathrm{h}$ as the VPD during the day increased (figure 2A). The $\mathrm{CO}_{2}$ assimilation rates of DP and $\mathrm{HP}$ were higher in the morning for both evaluations (figure $1 \mathrm{~A}$ and 1B). In the first evaluation, while the mean photosynthetic rate of the HP was approximately $8.3 \mu \mathrm{mol} \cdot \mathrm{m}^{-2} \cdot \mathrm{s}^{-1}$ at $8: 30$ $\mathrm{h}$, DP showed values of around $5.8 \mu \mathrm{mol} . \mathrm{m}^{-2} . \mathrm{s}^{-1}$. From 9:00 $\mathrm{h}$ onwards the photosynthetic rates of HP began to decrease probably because of the rise in temperature and solar radiation (figure $2 \mathrm{~A}$ ), while DP showed approximately the same rates shown before. Thus, as stomata of DP closed there was a decrease in photosynthesis and transpiration (figures 1A, 3A and 4A), indicating an adaptation of these plants to diminish water loss.

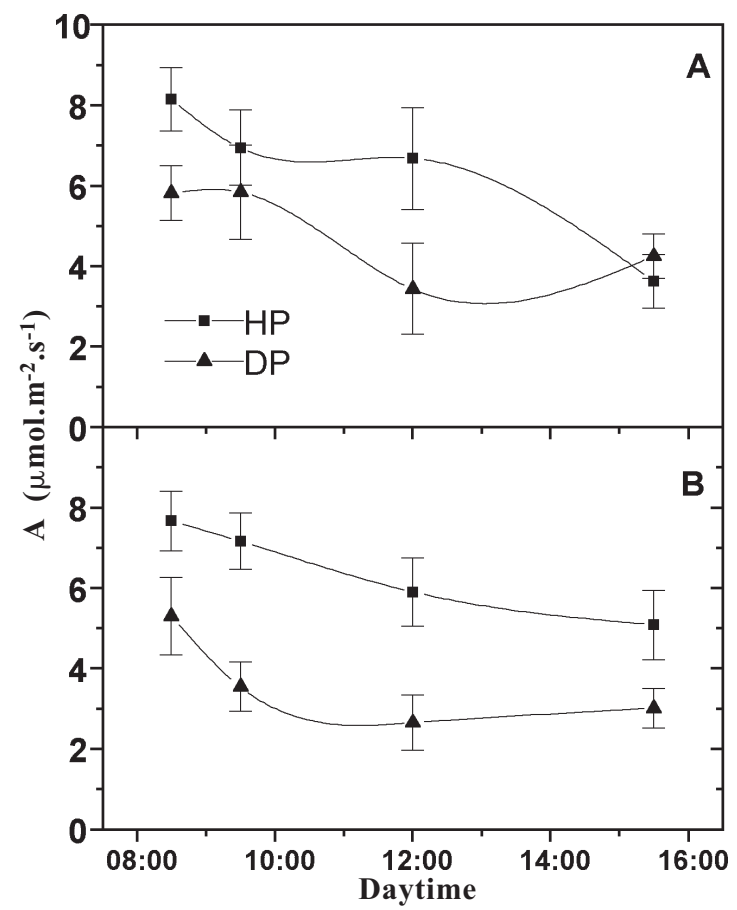

Figure 1. Effect of $\mathrm{CVC}$ on $\mathrm{CO}_{2}$ assimilation $(A)$ of "Pera" orange trees grafted on" "Rangpur" rootstocks in two evaluation dates, (A) 20 and (B) 26 months after Xylella fastidiosa inoculation. HP healthy plants; DP diseased plants.



Figure 2. Photosynthetically photon flux density (PPFD), air temperature $(\mathrm{T})$, vapor pressure deficit between the air and the leaf(VPD) during the measurement days at (A) 20 and (B) 26 months after Xylella fastidiosa inoculation.

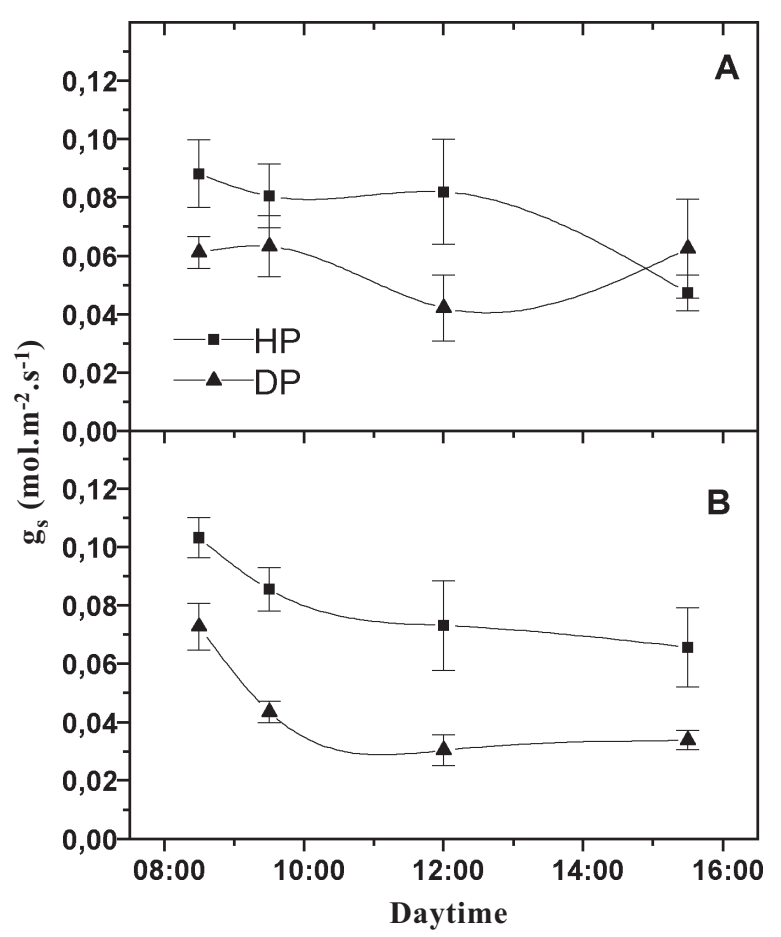

Figure 3. Effect of CVC in stomatal conductance $\left(g_{s}\right)$ of "Pera" orange trees grafted on"“Rangpur" rootstocks in two evaluation dates, (A) 20 and (B) 26 months after Xylella fastidiosa inoculation. HP healthy plants; DP diseased plants. 
In general, photosynthesis, stomatal conductance and transpiration on the first evaluation date in DP were lower than for HP throughout the day, except at the end of the afternoon. Peach trees infected with Xylella fastidiosa also showed reductions in $\mathrm{CO}_{2}$ assimilation and stomatal conductance (Anderson and French, 1987).

Possibly, gas exchanges in CVC plants were altered because the xylem was blocked, thereby decreasing the water movement capacity. On the first evaluation date it was observed that the leaf water potential of DP at 14:00 h was lower than that of HP (data not shown). In addition, these plants were more sensitive to variations in temperature and VPD, showing a decrease of the stomatal conductance (Gomes et al., 1999; Medina et al., 2000). The decrease in leaf water potential of DP, with the consequent appearance of wilt symptoms during the day, might be related to the deposition of bacterial gum and to the presence of tyloses and bacterial aggregates in the xylem vessels.

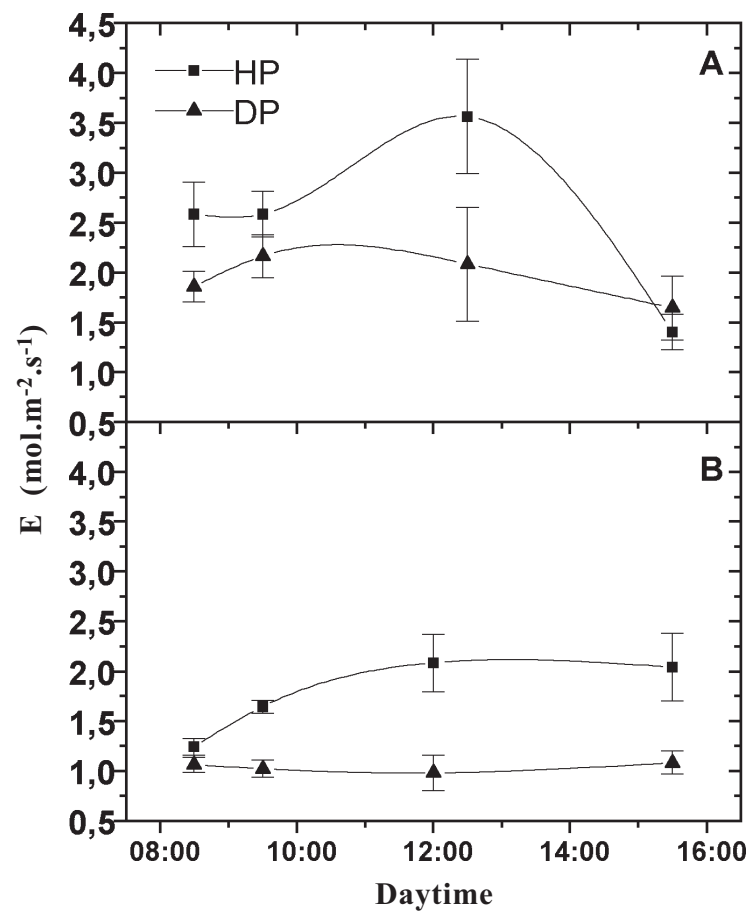

Figure 4. Effect of CVC on transpiration $(E)$ of "Pera" orange trees grafted on"“Rangpur" rootstocks in two evaluation dates, (A) 20 and (B) 26 months after Xylella fastidiosa inoculation. HP healthy plants; DP diseased plants.

Machado et al. (1994) observed that citrus leaves with CVC showed water shortage symptoms, suggesting that these symptoms may result from an increase in the resistance to xylem water flow and not to alterations in the stomata functioning. In citrus affected with a disease known as "decline", that also affects the water relations, the obstructions observed in the xylem lumen were responsible for the decrease in the water flow, resulting in a decrease of stomatal conductance and photosynthesis (Cohen et al., 1983; Brlansky et al., 1984).

On the second evaluation date, photosynthesis and stomatal aperture in DP were always lower than for HP (figures 1B and 3B). Transpiration rates in HP and DP were similar at 8:30 h but significantly different at 9:30 h, 12:00 h and 16:00 h (figures 4A). Although transpiration is controlled mainly by stomatal opening, photosynthesis in plants can also be affected by non-stomatal factors, such as loss of efficiency in the photosystem reaction centers and decrease of activity of photosynthetic enzymes, such as Rubisco. The mechanism by which Rubisco activity is reduced is not fully understood but it may consist of an unbalanced proportion between biosynthesis and biodegradation of the enzyme (Vu et al., 1987; Vu and Yelenosky, 1988b).

Cherry tree leaves infected with Blumeriella jaapii, the "cherry tree leaf spot disease" pathogen, led to reduced net photosynthesis during all stages of disease development (Niederleitner and Knoppik, 1997). Although a continuous decrease in the electron transport rates was observed, $\mathrm{CO}_{2}$ fixation was the most affected parameter, indicating that the infection interferes with enzymatic processes in the Calvin cycle.

Tan and Whitlow (2001) reported reduced photosynthesis in Catharanthus roseus leaves after inoculation with two strains of phytoplasms. The photoinhibition resulted from activity of the photoprotective processes before the damage of the photosystem II reaction center (PSII) while changes in $g_{s}$ were not correlated with changes in abscisic acid concentrations. Gomes et al. (2003) also observed a lack of correlation between $g_{s}$ and abscisic acid after two years of bacterial infection in orange trees infected with Xylella fastidiosa. However, in some cases, photosynthesis declines without affecting stomatal conductance, as reported by Sadras et al. (2000) for sunflower inoculated with Verticillium dahliae.

Plants with CVC present variegated leaves. The leaves used for the photosynthetic measurements in this study presented a low symptom index ("3 $\%$ type", with some yellow marking, according to Amorim et al., 1993). Therefore, some decrease in the pigment contents may have contributed to the reduction of photosynthetic rates. 


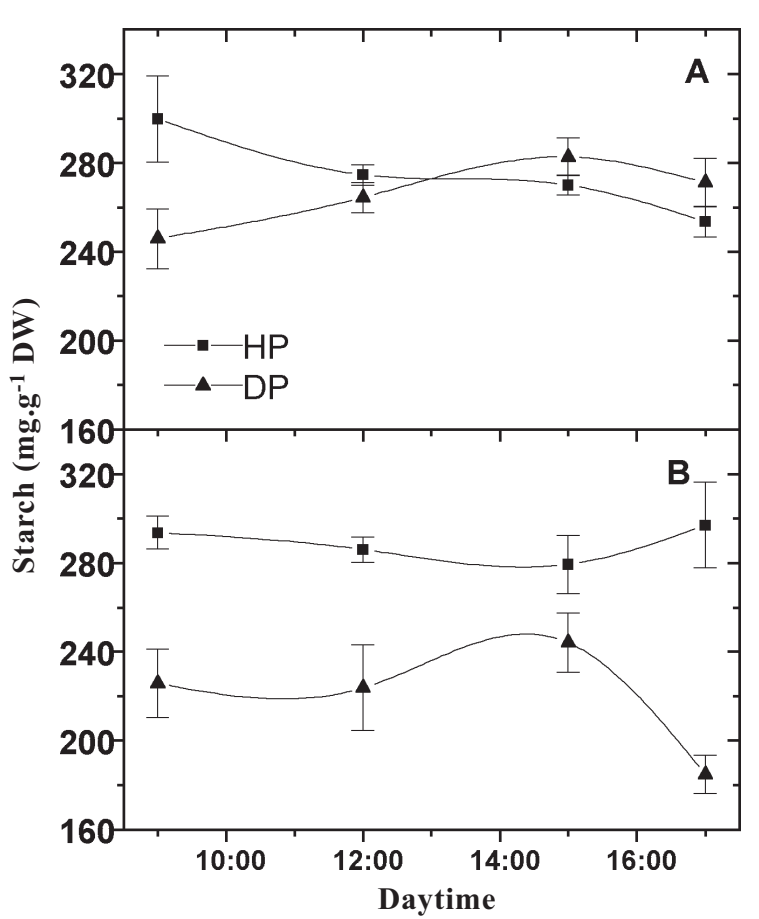

Figure 5. Effect of CVC on the starch content of leaves of "Pera" orange trees grafted on"“Rangpur" rootstocks in two evaluation dates, (A) 20 and (B) 26 months after Xylella fastidiosa inoculation. HP healthy plants; DP diseased plants.

Deficiency in carbohydrate supply is not usually observed in citrus because starch accumulates in several plant organs, including leaves (Goldschmidt and Koch, 1996; Ruiz et al., 2001). Starch reserves in citrus are formed even during fruit growth and this capacity to accumulate starch might be related to the fact that citrus is perennial and photosynthesis occurs throughout the year.

In the present study, HP and DP showed high

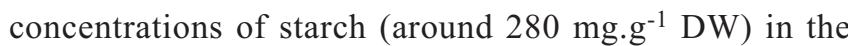
leaves at both evaluation dates (figures $5 \mathrm{~A}$ and $5 \mathrm{~B}$ ). However, on the second evaluation date starch was markedly lower in DP (figure 5B). This may be related to the energy availability in these plants, as there was a significant depression in photosynthesis.

Plants with CVC are usually deficient in K (Quaggio, 1988; Vitti et al., 1989). $\mathrm{K}$ is an important nutrient for carbohydrate metabolism in citrus leaves and its deficiency results in low starch concentration and greater concentration of reducing sugars, accompanied by an increase in the activities of $\beta$ amylases and acid invertase (Lavon et al., 1995). Vine leaves infected with Xylella fastidiosa also showed $\mathrm{K}$ deficiency and low starch concentration (Goodwin et al., 1988).

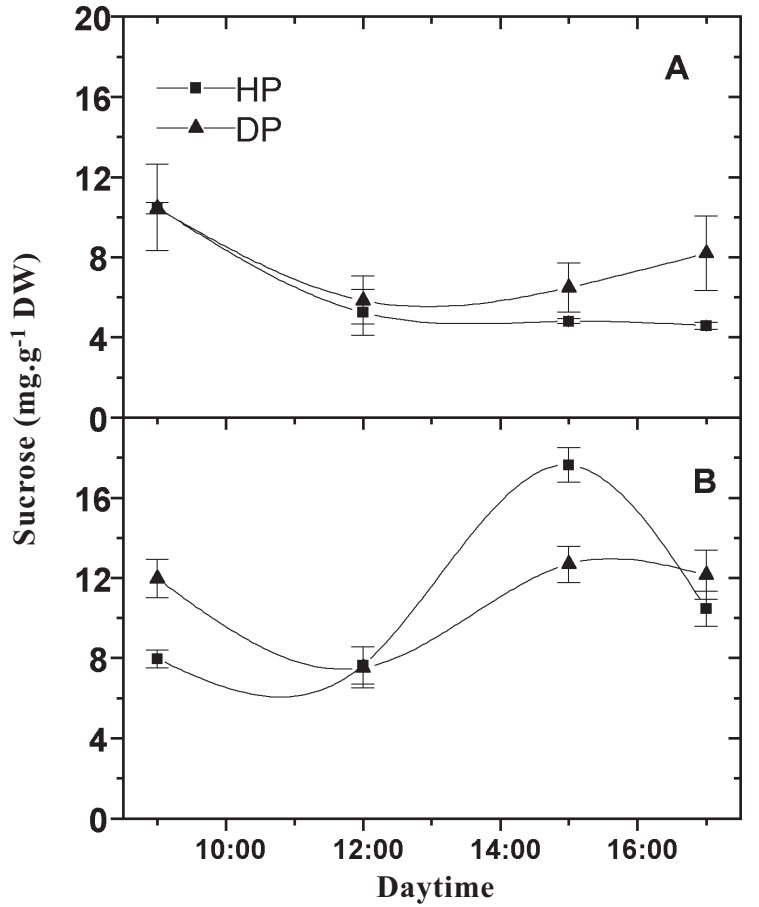

Figure 6. Effect of CVC on sucrose content of leaves of "Pera" orange trees grafted on" "Rangpur" rootstocks in two evaluation dates, (A) 20 and (B) 26 months after Xylella fastidiosa inoculation. HP healthy plants; DP diseased plants.

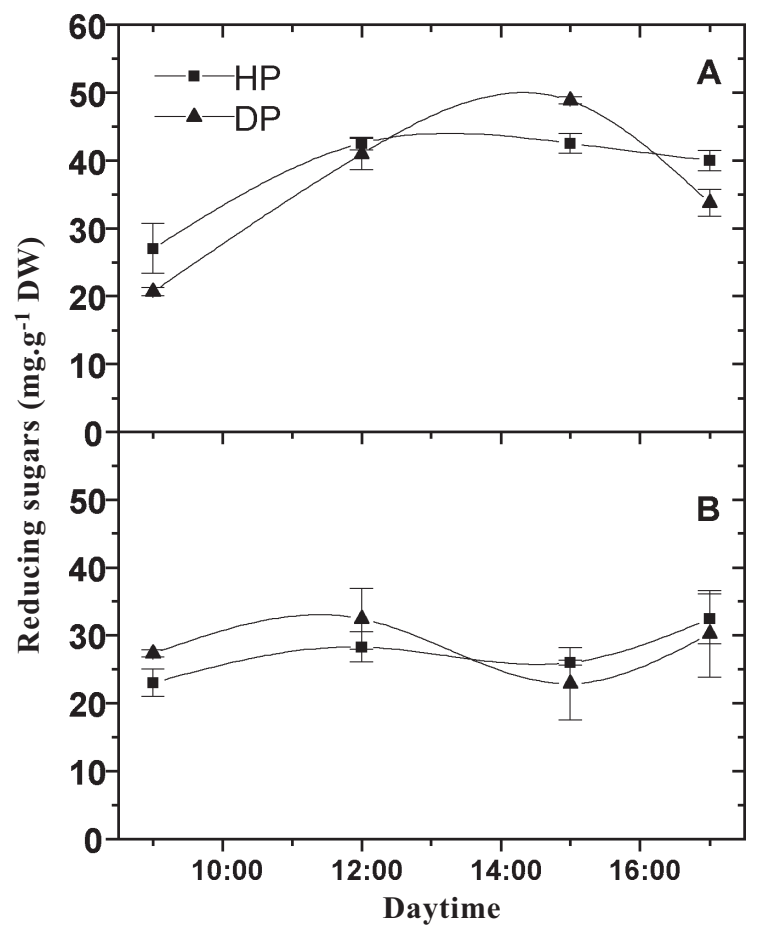

Figure 7. Effect of CVC on reducing sugars content of leaves of "Pera" orange trees grafted on" "Rangpur" rootstocks in two evaluation dates, (A) 20 and (B) 26 months after Xylella fastidiosa inoculation. HP healthy plants; DP diseased plants. 
In contrast to starch, it was not possible to establish a correlation between sucrose and reducing sugars with bacterial infection (figures 6 and 7). Other studies reported changes in sucrose and reducing sugars in leaves of tomato plants infected by fungi, followed by alterations in invertase activity (Zulu et al., 1991). Changes in invertase acid activity may modify the source-sink relationship in the leaves of infected plants, leading to an accumulation of soluble carbohydrates such as sucrose, glucose, fructose and phosphate-hexoses as observed in wheat leaves infected with mildew (Erysiphe graminis f.sp. tritici) (Wright et al., 1995a,b). However, infection of Picea abies by Chrysomyxa rhododendri caused a decrease in concentration of non-structural carbohydrates (Bauer et al., 2000).

Acknonowledgements: We thank Fapesp (98/16259-1) and Capes for financial support.

\section{REFERENCES}

Amorim L, Bergamin Filho A, Palazzo DA, Bassanezi RB, Godoy CV, Torres GAM (1993) Clorose variegada dos citros: uma escala diagramática para avaliação da severidade da doença. Fitopatol. Bras. 18:174-180.

Anderson PC, French WJ (1987) Biophysical characteristics of peach trees infected with phony peach disease. Physiol. Mol. Plant Pathol. 31:25-40.

Bauer H, Plattner K, Volgger W (2000) Photosynthesis in Norway spruce seedlings by the needle rust Chrysomyxa rhododendri. Tree Physiol. 20:211-216.

Brakke M, Allen Jr LH (1995) Gas exchange of Citrus seedlings at different temperatures, vapor-pressure deficits and soil water contents. J. Am. Soc. Hortic. Sci. 120:497-504.

Brlansky RH, Timmer LW, Lee RF, Graham JH (1984) Relationship of xylem plugging to reduced water uptake and symptom development in citrus trees with blight and blightlike declines. Phytopathology 74:1325-1328.

Chang CJ, Garnier M, Zreik L, Rossetti V, Bové JM (1993) Culture and serological detection of the xylem-limited bacterium causing citrus variegated chlorosis and its identification as a strain of Xylella fastidiosa. Curr. Microbiol. 27:137-142.

Cohen M, Pelosi RR, Brlansky RH (1983) Nature and location of xylem blockage in trees with citrus blight. Phytopathology 73:1125-1130.

Germanà C, Sardo V (1996) Relationship between net photosynthesis and transpiration rate in citrus trees. In: Proceedings of the VIII International Citrus Congress, Sun City, South Africa, vol 2, pp. 1117-1121.
Goldschmidt EE, Golomb A (1982) The carbohydrate balance of alternate bearing citrus trees and the significance for reserves for flowering and fruiting. J. Am. Soc. Hortic. Sci. 107:206-209.

Goldschmidt EE, Koch KE (1996) Citrus. In: Zamski E, Schaffer AA (eds), Photoassimilate Distribution in Plants and Crops: Source-Sink Relationships, pp.797-823. Marcel Dekker Inc., New York.

Gomes MMA, Medina CL, Machado EC, Machado MA, Lagôa AMMA (1999) Potencial da água da folha e ácido abscísico em Citrus sinensis L.(Osb.) com CVC e submetida ao estresse hídrico. Rev. Bras. Fisiol. Veg. 11 (Suppl):25.

Gomes, MMA, Lagôa, AMMA, Machado, EC, Medina, CL (2003) Abscisic acid and indole-3-acetic acid in orange trees infected by Xylella fastidiosa and submitted to cycles of water stress. Plant Growth Regul. 39:263-270.

Goodwin PH, De Vay JE, Meredith CP (1988) Physiological responses of Vitis vinifera cv. 'Chardonnay' to infection by the Pierce's disease bacterium. Physiol. Mol. Plant Pathol. 32:17-32.

Hill BL, Purcell AH (1995) Multiplication and movement of Xylella fastidiosa within grapevine and four other plants. Phytopathology 85:1368-1372.

Hill BL, Purcell AH (1997) Populations of Xylella fastidiosa in plants required for transmission by an efficient vector. Phytopathology 87:1197-1201.

Hopkins DL (1989) Xylella fastidiosa: xylem-limited bacterial pathogen of plants. Annu. Rev. Phytopathol. 27:271-290.

Lavon R, Goldschmidt EE, Salomon R, Frank A(1995) Effect of potassium, magnesium and calcium deficiencies on carbohydrate pools and metabolism in Citrus leaves. J. Am. Soc. Hortic. Sci 120:54-58.

Lima JEO, Coutinho A, Roberto SR, Miranda VS, Carlos EF, Salva R Massari C (1996) New developments on Citrus Variegated Chlorosis research at Fundecitrus, Brazil. In: Proceedings of the VIII International Citrus Congress, Sun City, South Africa, vol 1, pp. 435-439.

Machado EC, Quaggio JA, Lagôa AMA, Ticelli M, Furlani PR (1994) Trocas gasosas e relações hídricas em laranjeiras com clorose variegada dos citros. Rev. Bras. Fisiol. Veg. 6:53-57.

Medina CL, Machado EC, Gomes MMA (1999) Condutância estomática, transpiração e fotossíntese em laranjeiras 'Valência' sob deficiência hídrica. Rev. Bras. Fisiol. Veg. 11: 29-34.

Medina CL, Machado EC, Gomes MMA, Lagôa AMMA, Machado MA (2000) Gas exchange and water relations of 'Pêra' orange tree infected with Xylella fastidiosa and submitted to successive water stress. In: Proceedings of the IX International Society of Citriculture Congress, Florida, USA.v.1. p.160-161. 
Medina CL, Nunes WMC, Machado MA, Machado EC (1998) Transmission of Xylella fastidiosa by spliced approach grafting In: XIV Conference of IOCV. Program and Abstracts, Campinas, SP. v.1. p.163 - 163

Niederleitner S, Knoppik D (1997) Effects of the cherry leaf spot pathogen Blumeriella jaapii on gas exchange before and after expression of symptoms on cherry leaves. Physiol. Mol. Plant Pathol. 51:145-153.

Pooler MR, Hartung JS (1995) Specific PCR detection and identification of Xylella fastidiosa strains causing citrus variegated chlorosis. Curr. Microbiol. 31:377-381.

Quaggio JA (1988) Distúrbios nutricionais em citros afetados por CVC. Ata da $1^{\text {a }}$ reunião do Grupo de Trabalho sobre CVC, Secretaria da Agricultura, SP.

Raschke K, Resemann A (1986) The midday depression of $\mathrm{CO}_{2}$ assimilation in leaves of Arbutus unedo L.: diurnal changes in photosynthetic capacity related to changes in temperature and humidity. Planta 168:546-558.

Rossetti V, Garnier M, Bové JM, Beretta MJG, Teixeira ARR (1991) Occurrence of xylem-restricted bacteria in sweet orange trees affected by chlorosis variegation, a new citrus disease in Brazil. Plant Prot. Bull. 39:115-116.

Rossetti VV (2001) Manual ilustrado de doenças dos citros. Fealq/Fundecitrus, Piracicaba, 207p.

Ruiz R, Garcia-Luis A, Monerri C, Guardiola JL (2001).Carbohydrate availability in relation to fruitlet abscission in Citrus. Ann. Bot. 87:805-812.

Sadras VO, Queiroz F, Echarte L, Escande A, Pereyra VR (2000) Effect of Verticillium dahliae on photosynthesis, leaf expansion and senescence of field-grown sunflower. Ann. Bot. 86:1007-1015.

Sinclair TR, Allen Jr LH (1982) Carbon dioxide and water vapor exchange of leaves on field-grown citrus trees. J. Exp. Bot. 33:1166-1775.

Somogyi M (1952) Notes on sugar determination. J. Biol. Chem. 195:19-23.

Syvertsen JP (1999) Physiological determinants of citrus tree growth and development. In: Proceedings of the First International Symposium of Fruit Crop I-Production and Quality of Citrus Fruits, Botucatu, Brasil, pp. 123-160.
Syvertsen JP, Lloyd J (1994) Citrus. In: Schaffer B, Andersen P (eds), Handbook of Environmental Physiology of Fruit Crops: Sub-tropical and Tropical Crops., vol. 2, pp.65-99. CRC Press, Boca Raton.

Tan PY, Whitlow T (2001) Physiological responses of Catharanthus roseus (periwinkle) to ash yellows phytoplasmal infection. New Phytol. 150:757-769.

Vitti GC, Marchi RJ, Borella ML, Vaz Filho D (1989) Estudo de prováveis desequilíbrios nutricionais em pomares cítricos no município de Colina-SP. In: Boletins da FCAV/ Unesp, Jaboticabal, Brasil, 12p.

Vu JCV, Allen Jr LH, Bowes G (1987) Drought stress and elevated $\mathrm{CO}_{2}$ effects on soybean ribulose bisphosphate carboxylase activity and canopy photosynthetic rates. Plant Physiol. 83:573-578.

Vu JCV, Yelenosky G (1988a) Water deficit and associated changes in some photosynthetic parameters in leaves of 'Valencia' orange (Citrus sinensis L. Osbeck.) Plant Physiol. 88:375-378.

Vu JCV, Yelenosky G (1988b) Solar irradiance and drought stress effects on the activity and concentration of ribulose bisphosphate carboxylases in 'Valencia' orange leaves. Israel J. Bot. 37:245-256.

Waring RH (1991) Responses of evergreen trees to multiple stresses. In: Mooney HA, Winner WE, Pell EJ (eds), Responses of Plants to Multiple Stresses, pp.371-390. Academic Press Inc., New York.

Wright DP, Baldwin MC, Shephard MC, Scholes JD (1995a) Source-sink relationships in wheat leaves infected with powdery mildew. I. Alterations in carbohydrate metabolism. Physiol. Mol. Plant Pathol. 47:237-253.

Wright DP, Baldwin MC, Shephard MC, Scholes JD (1995b) Source-sink relationships in wheat leaves infected with powdery mildew. II. Changes in the regulation of the Calvin cycle. Physiol. Mol. Plant Pathol. 47:255-267.

Zulu JN, Farrar JF, Whitbread R (1991) Effects of phosphate supply on wheat seedlings infected with powdery mildew: carbohydrate metabolism of first leaves. New Phytol. 118:553-558. 